\title{
Persepsi Mahasiswa Hukum Ekonomi Syariah (Hes) Terhadap Mata Kuliah Ekonomi Konvensional
}

\author{
Amilis Kina \\ IAIN Tulungagung \\ Email:Iskina2016@gmail.com
}

\section{Kata kunci:}

Persepsi, Ekonomi

Konvensional

\section{Keywords:}

Perception, Conventional Economics

Amilis Kina, Persepsi Mahasiswa Hukum Ekonomi Syariah (Hes) Terhadap Mata Kuliah Ekonomi Konvensional. Akuntabilitas: Jurnal Ilmu-Ilmu Ekonomi, 12(2), 52-74. https://doi.org/10.35457/akuntab ilitas.v12i1.720,

\begin{abstract}
ABSTRAK
Untuk mengetahui persepsi mahasiswa hukum ekonomi syariah terhadap matakuliah ekonomi konvensional dibandingkan dengan matakuliah ekonomi syariah, mengetahui relevansi keduanya hingga tingkat keberhasilan dan mengetahui faktor terbentuknya persepsi terhadap matakuliah konvensional ini. Jenis penelitian kuantitatif dan berupa data sekunder yang menuangkan angka, mulai dari pengumpulan data, penafsiran terhadap data tersebut, serta penampilan hasilnya. Populasi penelitian ini adalah mahasiswa Hukum Ekonomi Syariah IAIN Tulungagung. Dengan menyajikan sampelnya yaitu mahasiswa jurusan Hukum Ekonomi Syariah IAIN Tulungagung yang sedang mengambil mata kuliah ekonomi konvensional sebanyak 100 mahasiswa diambil dari enam kelas hukum ekonomi syariah. Penelitian ini berdasarkan kualitatif dengan data kuantitatif, data akan kita sajikan dalam bentuk grafik kemudian diperjelas dengan uraian dibawahnya. Responden memiliki persepsi yang positif tentang pentingnya mempelajari ekonomi konvensional dan relevansinya dengan peningkatan wawasan bidang keilmuan ekonomi konvensional. Responden percaya bahwa ekonomi konvensional dapat membantu masalah-masalah hukum tertentu. Dan ekonomi konvensional dapat membuat peluang kemudahan dan kelancaran dalam menjalani karir nantinya sebagai penegak hukum. Responden terbukti memiliki persepsi positif terhadap pembelajaran ekonomi konvensional. Pembelajaran tersebut memberi manfaat dalam mendapatkan penilaian yang baik. Ditemukan bahwa terdapat banyak factor yang mempengaruhi mahasiswa HES dalam mempelajari ekonomi konvensional. Dapat dilihat bahwasanya factor penting berada pada factor SDM yaitu mahasiswa itu sendiri dan dosen sebagai penyampai materi. Motivasi, cara pandang mahasiswa serta wawasan dosen penyampai materi diyakini oleh para responden sebagai factor utama yang berpengaruh terhadap keberhasilan mereka dalam mempelajari mata kuliah ekonomi konvensional ini.Faktor-faktor yang dianggap menghambat proses pembelajaran sistem informasi di jurusan HES adalah sebagai berikut:Minat dan motivasi yang rendah untuk belajar ekonomi konvensional;Persepsi negative mahasiswa tentang relevansi sistem informasi dengan bidang ilmu ekonomi konvensional.
\end{abstract}

\section{ABSTRACT}

To find out the perception of Islamic economics law students against conventional economics courses compared to Islamic economics courses, find out the relevance of both to the level of success and know the factors forming the perception of this conventional course. This type of quantitative research and in the form of secondary data that pour numbers, starting from data collection, interpretation of the data, and the appearance of the results. The population of this research is students of Islamic Economics Law IAIN Tulungagung. By presenting a sample of IAIN Tulungagung Islamic Economics Law majoring students taking conventional economics courses as many as 100 students were drawn from six sharia economics law classes. This research is based on qualitative data with quantitative data, we will present the data in graphical form then clarified with the description below. Respondents have positive perceptions about the importance of 
studying conventional economics and its relevance to increasing insight into the field of conventional economic scholarship. Respondents believe that conventional economics can help with certain legal issues. And conventional economics can create opportunities for ease and smoothness in undergoing a career later as law enforcement. Respondents proved to have a positive perception of conventional economic learning. This learning has benefits in getting good judgment. It was found that there are many factors that influence HES students in studying conventional economics. It can be seen that the important factor is the HR factor, namely the students themselves and the lecturer as the material deliverers. Motivation, students' perspectives and the insight of lecturers delivering the material are believed by the respondents as the main factors influencing their success in studying this conventional economic course. Factors that are considered to hinder the learning process of information systems in the HES department are as follows: Interest and motivation low for conventional economics learning; students' negative perceptions about the relevance of information systems to conventional economics.

\section{PENDAHULUAN}

Didalam ilmu sosial terdapat juga ilmu ekonomi. Cara manusia mengatur diri dalam memenuhi kebutuhan hidupnya merupakan sasaran utama dalam kajian ilmu ekonomi (Sa"id Sa"ead Marthon,2004). Untuk memenuhi kebutuhan itu, masyarakat turut mempengaruhi dan dipengaruhi oleh kegiatan lingkungannya. Dalam ruang lingkup masyarakat ini ikhtiar manusia ditentukan oleh norma-norma, aturan kelakuan, cara-cara sesuatu dikerjakan dalam masyarakat, yang tercermin dalam pengaturan kelembagaan (institutional arrangement) dalam masyarakat, dan membentuk sistem ekonomi.

Pada tahun 1983, pemerintah Indonesia pernah berencana menerapkan "sistem bagi hasil" dalam berkreditan yang merupakan konsep dari perbankan syariah. Saat itu kondisi perbankan Indonesia memang parah-parahnya karena Bank Indonesia tidak bisa mengendalikan tingkat suku bunga di bank-bank yang membumbung tinggi. Sehingga pemerintah mengeluarkan deregulasi tanggal 1 Juni 1983 yang menimbulkan kemungkinan bank mengambil untung dari bagi hasil sistem kredit.

Namun lima tahun kemudian, pemerintah menganggap bisnis perbankan harus dibuka seluas-luasnya untuk menunjang pembangunan. Dan tanggal 27 Oktober 1988, pemerintah pun mengeluarkan Paket Kebijaksanaan Pemerintah Bulan Oktober (PAKTO) untuk meliberalisasi perbankan. Dengan demikian, meskipun lebih banyak bank konvensional yang berdiri, beberapa bank daerah yang berasaskan syariah juga mulai bermunculan. 
Bank Islam pertamakali didirikan di Indonesia pada Tahun 1991, yang diberi nama Bank Muamalat. Bank Muamalat ini merupakan cikal bakal lahirnya perbankkan syariah di Indonesia. Kemudian pada tahun 1992 Bank Muamalat pertama kali beroperasi sebagai bank islam satu-satunya diantara bank konvensional lainnya. Sebelum ada Bank Muamalat ini, perekonomian di Indonesia menggunakan sistem perbankkan konvensional.

Dengan banyaknya perkembangan ilmu syariah, maka sekarang ini banyak bermunculan perbankkan syariah yang baru. Ekonomi konvensional memang masih lebih diatas ekonomi syariah. Para ekonom mempridiksi tahun-tahun yang akan datang ekonomi syariah akan berkembang lebih pesat dari ekonomi konvensional (Agus Marimin,2015).

Jika dilihat dalam konteks masyarakat, 'Hukum Ekonomi Syariah' berarti Hukum Ekonomi Islam yang digali dari sistem Ekonomi Islam yang ada dalam masyarakat, yang merupakan pelaksanaan Fiqih di bidang ekonomi oleh masyarakat. Pelaksanaan Sistem Ekonomi oleh masyarakat membutuhkan hukum untuk mengatur guna meciptakan tertib hukum dan menyelesaikan masalah sengketa yang pasti timbul pada interaksi ekonomi. Dengan kata lain Sistem Ekonomi Syariah memerlukan dukungan Hukum Ekonomi Syariah untuk menyelesaikan berbagai sengketa yang mungkin muncul dalam masyarakat.

Di dalam produk hukum ekonomi syariah secara kongkret di Indonesia khususnya dapat dilihat dari pengakuan atas fatwa Dewan Syariah Nasional, sebagai hukum materiil ekonomi syariah, untuk kemudian sebagiannya dituangkan dalam PBI atau SEBI. Demikian juga dalam bentuk undang-undang, seperti contohnya Undang-undang No. 38 Tahun 1999 Tentang Pengelolaan Zakat, Undang-undang No. 21 Tahun 2008 Tentang Perbankan Syariah, dan lain sebagainya, diharapkan dapat mengisi kekosongan perundang-undangan dalam bidang ekonomi syaraiah.

Untuk memenuhi dan mengantisipasi kemungkinan peluang yang ada, maka 'hukum' seharusnya mampu memberikan solusi yang sesuai dengan perkembangan dunia bisnis. Dalam kontek ini, kajian hukum yang diperlukan ialah kajian hukum ekonomi dan kajian hukum bisnis yang dipadukan dengan prinsip-prinsip Islam. 
Dengan demikian, diharapkan hukum ekonomi/hukum bisnis, pada hakikatnya juga selalu dapat dan mampu berkembang sesuai kebutuhan jaman.

Pertama yang akan dilakukan yaitu menawarkan dua mata kuliah Ekonomi Konvensional yang berkaitan dengan Hukum Ekonomi Syariah yaitu, Pengantar Akuntansi Konvensional dan Perpajakan untuk semakin mempertajam daya saing lulusan. Kedua mata kuliah tersebut penting untuk dikuasai dan dipahami oleh semua mahasiswa Hukum Ekonomi Syariah. Ilmu yang didapat dalam mata kuliah tersebut juga membutuhkan pemahaman mereka tentang bidang ilmu utama (yaitu Hukum ekonomi syariah) yang sudah mereka pelajari. Salah satu contoh adalah mata kuliah Akuntansi Islam membutuhkan pemahaman mahasiswa tentang alur transaksi akuntansi pada setiap proses agar dapat menghasilkan informasi akuntansi yang akurat dan jelas sebagai output.

Sebagaimana mata kuliah lain,efektifitas pencapaian tujuan ditawarkannya mata kuliah yang berkaitan dengan ekonomi konvensional diatas dipengaruhi oleh banyak hal seperti : ketersediaan fasilitas, faktor-faktor yang datang dari diri pengajar,maupun factor-faktor yang berasal dari diri mahasiswa itu sendiri. Dari kedua hal yang mempengaruhi efektivitas pencapaian tujuan perkuliahan,penulis tertarik untuk meneliti faktor yang datang dari diri mahasiswa itu sendiri. Faktor yang datang dari diri mahasiswa bisa bermacam-macam seperti kedisiplinan,kesadaran,persepsi, dan lain lain. Salah satu hal yang penting adalah bagaimana persepsi mahasiswa terhadap mata kuliah mata kuliah pengantar akuntansi dan perpajakan yang dapat mempengaruhi keberhasilannya dalam memahami / mempelajari mata kuliah tersebut.

Pengertian persepsi sering disamakan dengan pandangan atau anggapan seseorang terhadap sesuatu karena dalam istilah persepsi terdapat interpretasi pandangan atau tanggapan seseorang. Menurut Sarlito W. Sarwono (2012) menjelaskan bahwa persepsi adalah suatu kemampuan seseorang untuk membedakan, mengelompokkan, memfokuskan, dan sebagainya, kemudian dapat diinterpretasikan. Persepsi itu sendiri diartikan sebagai proses akhir dari aktifitas observasi yang dimulai dengan proses penginderaan, yaitu proses diterimanya 
stimulus oleh indera,kemudian stimulus menimbulkan perhatian yang diteruskan ke otak dan dilanjutkan dengan kesadaran individu. Kesadaran inilah yang dinamakan persepsi. Dengan persepsi,individu dibantu untuk menyadari dan mengerti tidak hanya tentang hal-hal yang berada di sekitarnya akan tetapi juga tentang hal yang terdapat didalam diri individu yang bersangkutan.

Untuk mengukur keberhasilan mahasiswa dalam belajar ekonomi konvensional, maka persepsi merupakan salah satu faktor yang bisa untuk mengukur, memotivasi dan mempengaruhi mahasiswa dalam proses belajarnya. Akan tetapi bagaimana fenomena Persepsi dan Pandangan Mahasiswa HES terhadap mata kuliah ekonomi Konvensional dibandingkan dengan matakuliah lainnya, Persepsi atau Pandangan mahasiswa HES terhadap relevansi bidang ilmu ekonomi konvnsional, Seberapa besar persepsi mahasiswa HES mempengaruhi tingkat keberhasilannya dalam mempelajari mata kuliah ekonomi konvensional dan faktor-faktor apa saja yang dapat mempengaruhi terbentuknya persepsi mahasiswa HES terhadap mata kuliah ekonomi konvensional.

Sistem Ekonomi islam adalah ilmu pengetahuan sosial yang mempelajari masalah masalah ekonomi rakyat yang didasari oleh nilai - nilai Islam. Sistem Ekonomi Islam merupakan sistem ekonomi yang berorientasi rahmatan lil'alamin, Namun dalam perkembangannya, sistem ekonomi Islam hanya dikenal dalam ruang lingkup yang sempit yakni hanya pada lembaga - lembaga keuangan syariah seperti bank-bank syariah, pegadaian syariah dan lain-lain. Padahal ruang lingkup ekonomi itu meliputi sektor riil seperti perdagangan, pertanian, maupun perindustrian.

Dalam penelitian ini, peneliti bermaksud untuk mengetahui persepsi mahasiswa hukum ekonomi syariah terhadap matakuliah ekonomi konvensional dibandingkan dengan matakuliah ekonomi syariah, mengetahui relevansi keduanya hingga tingkat keberhasilan dan mengetahui faktor terbentuknya persepsi terhadap matakuliah konvensional ini. Jenis penelitian kuantitatif dan berupa data sekunder yang menuangkan angka, mulai dari pengumpulan data, penafsiran terhadap data tersebut, serta penampilan hasilnya dalam penelitian ini. 


\section{METODE PENELITIAN}

Jenis penelitian ini adalah penelitian kuantitatif dan berupa data sekunder. Variabel penelitian pada dasarnya adalah segala sesuatu yang berbentuk apa saja yang ditetapkan oleh peneliti untuk dipelajari sehingga diperoleh informasi tentang hal tersebut, kemudian ditarik kesimpulannya.

Penelitian akan lebih di fokuskan pada upaya menggali opini terkait dengan persepsi para mahasiswa jurusan hukum ekonomi syariah terhadap segala aspek pembelajaran mata kuliah ekonomi syariah. Tujuannya adalah untuk bisa mengidentifikasi factor-faktor yang mempengaruhi persepsi mahasiswa dan bagaimana hal itu bisa mempengaruhi performance mahasiswa tersebut pada mata kuliah sistem informasi ekonomi konvensional yang mereka ambil. Diharapkan juga akan bisa mengidentifikasi hambatan-hambatan yang bisa mempengaruhi persepsi dan performance mereka dalam proses belajar.

\section{Teknik Pendekatan Penelitian}

Penelitian ini menggunakan pendekatan kuantitatif, karena penelitian ini disajikan dengan angka-angka. penelitian kuantitatif adalah pendekatan penelitian yang banyak dituntut menuangkan angka, mulai dari pengumpulan data, penafsiran terhadap data tersebut, serta penampilan hasilnya.

\section{Teknik Penetapan Responden}

Teknik pengumpulan responden dalam penelitian terdiri :

\section{Observasi}

Observasi yaitu proses pencatatan pola perilaku subyek atau orang, obyek atau bendaatau kejadian yang sitematik tanpa adanya pertanyaan atau komunikasi dengan individu-individu yang diteliti. Kelebihan metode observasi terletak pada data yang dikumpulkan umumnya lebih akurat dan bebas dari response bias. Metode ini dapat menghasilkan data yang lebih rinci mengenai perilaku subyek, benda atau kejadian obyek. Peninjauan lapangan (lokasi) penelitian di IAIN Tulungagung, baik observasi awal maupun dalam pengumpulan data dengan cara kuesioner.( Nur indriantoro,2002). Peninjauan lapangan (lokasi) penelitian di IAIN 
Tulungagung, baik observasi awal maupun dalam pengumpulan data dengan cara kuesioner.

\section{Kuesioner}

Kuisoner adalah sejumlah pertanyaan tertulis yang digunakan untuk memperoleh informasi dari responden dalam arti laporan tentang responden. Kuesioner digunakan untuk menyebut metode maupun instrumen. Jadi dalam menggunakan metode angket atau kuesioner instrumen yang dipakai adalah angket atau kuesioner. Pengumpulan kuesioner dengan menyebar angket kepada mahasiswa hukum ekonomi syariah sebanyak 100 anak dari 6 kelas pada prodi hukum ekonomi syariah.

Metode penelitian penulis pergunakan dalam menyusun adalah metode penelitian defkriftif. Menurut Sugiono (2010), penelitian yang digunakan untuk meneliti pada kondisi objek alamiah di data Metode pengumpulan data yang digunakan dalam penelitian ini adalah metode observasi. Kuesioner ini didistribusikan pada 100 mahasiswa dari 6 kelas hukum ekonomi syariah yang diikuti oleh mahasiwa hes semester ganjil/genap tahun akademik 2017/2018.dimana peneliti merupakan instrumen kunci.

\section{Populasi dan Sampel}

Populasi adalah wilayah generalisai yan terdiri atas obyek atau subyek yang mempunyai kualitas dan karakteristik tertentu yang ditetapkan oleh peneliti untuk dipelajari dan kemudian ditarik kesimpulannya (Sugiyono, 2005). Populasi penelitian ini adalah mahasiswa Hukum Ekonomi Syariah IAIN Tulungagung. Sementara sampelnya adalah mahasiswa jurusan Hukum Ekonomi Syariah IAIN Tulungagung yang sedang mengambil mata kuliah-mata kuliah ekonomi konvensional.

Sampel adalah sebagian atau wakil populasi yang diteliti ( Suharsimi Arikunto,2002). Sampel diambil denga menggunakan metode Simple Random Sampling dari mahasiswa hukum ekonomi syariah yang sudah selesai mengambil mata kuliah ekonomi konvensional dan saat ini sedang mengambil mata kuliah lanjutan lainnya 


\section{Analisis Deskriptif Kualitatif}

Desain penelitiannya secara total dan lebih banyak mengkonstruksi format penelitian dan strategi memperoleh data di lapangan tapi tetap longgar dan terbuka terhadap teori. Atau starategi yang lebih banyak menganalisis permukaan data dan hanya memperhatikan proses-proses kejadian suatu fenomena, bukan pendalaman data atau makna data (Burhan Bungin. 2011).

Penelitian yang bertujuan menjelaskan fenomena yang ada dengan menggunakan angka-angka untuk mencadarkan karakteristik individu atau kelompok. Penelitian ini menilai sifat dari kondisi-kondisi yang tampak. Tujuan dalam penelitian ini dibatasi untuk mengambil karakteristik sesuatu sebagaimana adanya (Syamsuddin, dkk. 2011).

Jadi, Penelitian ini berdasarkan kualitatif dengan data kuantitatif. Data akan kita sajikan dengan data-data grafik, menerangkan matakuliah ekononomi konvensional ini apakah menyenangkan atau tidak, bermanfaat ataukah tidak untuk mahasiswa HES.

\section{HASIL DAN PEMBAHASAN}

\section{A. Analisis Hasil Penelitian}

Secara berturut-turut akan disajikan tentang gambaran deskriptif tentang persepsi mahasiswa HES, mata kuliah ekonomi konvensional dan hubungannya dengan kinerja mahasiswa. Ketiga jenis data yang akan dideskripsikan ini terdiri dari dua variabel bebas, yaitu persepsi mahasiswa HES dan matakuliah ekonomi konvensional, serta variabel terikat yaitu Kinerja mahasiswa yang diperoleh melalui angket yang dirancang oleh peneliti berdasarkan indikator-indikatornya.

Instrumen mahasiswa HES disusun dengan 22 butir pernyataan berdasarkan pada skala sikap model Likert yang dimodifikasi dengan menggunakan 4 option yaitu skoring 4 untuk selalu, 3 untuk sering, 2 untuk jarang, dan 1 untuk tidak pernah, hal ini berlaku untuk pernyataan positif dan sebaliknya bila pernyataan negatif. Responden mahasiswa HES terdiri dari 60 mahasiswa yang terdiri dari 19 orang mahasiswa laki-laki dan 43 orang mahasiswa berjenis kelamin perempuan. 
Bauran usia responden terdiri dari usia kurang dari 20 tahun 0, usia 20 tahun 13 orang mahasiswa, usia 21 tahun 22 orang mahasiswa, dan usia diatas 21 tahun 25 orang mahasiswa. Adapun matakuliah yang disenangi oleh mahasiswa HES adalah fiqih terdiri dari 9 orang mahasiswa, bahasa arab terdiri 33 orang mahasiswa, mata kuliah dasar 8 orang mahasiswa dan ekonomi konvensional (akuntansi dan perpajakan) 10 orang mahasiswa.Waktu jam kuliah dalam menerima matakuliah yang disenangi adalah jam ke 2 (08.40-10.20 WIB) 9 orang mahasiswa, jam ke 3 (10.20-12.00 WIB) 33 mahasiswa, jam ke 4 (13.00-14.40 WIB) terdiri dari 8 orang mahasiswa dan jam ke 5 dan jam ke 6 (14.40-16.20 WIB atau 16.20-18.00 WIB) sebanyak 10 orang mahasiswa.

Dalam seleksi pertanyaan ini, mahasiswa memberikan respon tentang matakuliah ekonomi konvensional diberikan tiap semester. Adapun yang sangat tidak setuju 10 orang mahasiswa, tidak setuju 32 orang mahasiswa, setuju 8 orang mahasiswa dan 10 orang mahasiswa sangat setuju. Respon terhadap matakuliah ekonomi konvensional menjadi jenis matakuliah wajib yang sangat tidak setuju 1 orang mahasiswa, setuju 7 orang mahasiswa, dan 52 orang mahasiswa sangat setuju. Latar belakang mahasiswa menjadika suatu persepsi tentang suatu keputusan yang diambil. Ada sebagian mahasiswa yang pernah sekolah atau kuliah dijurusan ekonomi/sosial. Adapun yang tidak pernah ada 8 orang mahasiswa dan 52 orang mahasiswa pernah sekolah atau kuliah dijurusan ekonomi/sosial. Dari responden terdapat 28 orang mahasiswa setuju matakuliah ekonomi konvensional sangat menambah wawasan. Dan selebihnya terdapat 32 orang mahasiswa mengganggap matakuliah ekonomi konvensional sedikit menambah wawasan. Yang sangat setuju matakuliah ekonomi konvenional dapat memberikan informasi mengenai fenomena sosial yang terjadi di lingkungan sekitarnya ada 49 orang mahasiswa dan yang setuju ada 11 orang mahasiswa. Diagram dapat dilihat dibawah ini.

Matakuliah ekonomi konvensional dapat memberikan pengetahuan dan menambah wawasan anda terhadap apa yang disampaikan oleh dosen, mahasiswa yang setuju ada 24 orang mahasiswa, 36 orang mahasiswa sangat setuju dengan pernyataan tersebut .Belajar mendiskusi kondisi ekonomi di kampus merupakan 
tempat efektif untuk belajar. Pendapat yang sangat setuju 29 orang mahasiswa, 31 orang mahasiswa setuju dengan pernyataan tersebut. Diagaram bisa dihihat dibawah ini. Responden pada penelitian ini adalah dari mahasiswa HES, yang notebane nya berlatar belakang dari ilmu hukum dan muamalah keislaman. Namun demikian respon mahasiswa hes suka dengan mata kuliah ekonomi konvensional sebanyak 60 orang mahasiswa. Sebanyak 26 orang mahasiswa sangat setuju mengenai jam perkuliahan yang sudah dijadualkan oleh fakultas, sedangkan sebanyak 34 orang mahasiswa menyetujuinya. Diagramnya bisa dilihat dibawah ini.

Metode dalam penyampaian dosen ke mahasiswa adalah dengan metode ceramah dan diskusi. Dengan metode ceramah diharapkan dosen merupakan salah satu informan bagi mahasiswa. Dan diskusi merupakan alat untuk menggali potensi mahasiswa untuk mengemukakan pendapatnya. Dengan metode tersebut ada 20 orang mahasiswa yang setuju dan selebihnya 40 orang mahasiswa yang sangat setuju dengan metode yang disampaikan oleh oleh dosen. Sedangkan metode dalam penyampaian dengan sistem diskusi dirasakan oleh responden sudah sesuai dengan kebutuhan dan sebayak 40 orang mahasiswa sangat setuju dengan metode diskusi ini dan yang 20 orang mahasiswa setuju dengan metode yang diterapkan. Sedangkan matakuliah ekonomi konvensional sudah mencakup semua masalah ekonomi di lapangan. Ada 5 orang mahasiswa yang beranggapan jika mata kuliah ekonomi konvensional tersebut tidak mencakup masalah ekonomi yang dihadapi. Dan sebanyak 43 orang mahasiswa beranggapan jika matakuliah ekonomi konvensional tersebut sudah menjadi miniatur di lapangan. Keterbatasan waktu dan jumlah SKS yang membatasi perkuliahan ekonomi konvensional secara mendalam. Sedangkan 12 orang mahasiswa merasa sangat setuju dengan matakuliah yang disajikan selama perkuliahan ekonomi konvensional.

Matakuliah ekonomi konvensional disajikan masih-masing 2 SKS. Adapun mata kuliah ekonomi konvensional adalah pengantar akuntansi dan perpajakan. Setiapa pertemuan 100 menit untukmasing-masing matakuliah. Keterbatasan waktu dan jumlah SKS yang membatasi perkuliahan ekonomi konvensional secara mendalam. Ada 50 orang mahasiswa berpendapat penambahan matakuliah ekonomi 
konvensional yang sangat diperlukan. Dan sebanyak 10 orang mahasiswa merasa penambahan jam perkuliahan ekonomi konvensional sangat diperlukan. Diagramnya dapat dilihat dibawah ini.

Dosen merupakan salah satu sumber informasi yang dibutuhkan oleh mahasiswa. Dosen sebagai penyampai informasi tersebut harus mempunyai kualifikasi kredibilitas yang tinggi, diantaranya berwawasan luas, mempunyai informasi tentang perkembangan ekonomi yang sedang terjadi dan mempunyai dasar keilmuan yang sesuai dengan matakuliah yang diampu khususnya ekonomi konvensional. Sebanyak 43 orang responden berpendapat sangat setuju dengan pernyataan diatas dan selebihnya sebanyak 17 orang mahasiswa setuju dengan kredibilitas dosen pengampu matakuliah ekonomi konvensioanal sedangkan bahasa merupakan alat untuk menyampaiakan informasi yang efektif. Dalam penyampaikan informasi khususnya di matakuliah ekonomi konvensional, dosen telah menggunakan dengan bahasa secara ilmiah dan responden sangat setuju sebnayak 23 orang mahasiswa dengan alasan untuk membiasakan bahasa ilmiahnya ekonomi konvensional. Dan selebihnya sebanyak 37 orang mahasiswa setuju dengan apa yang telah dosen ekonomi konvensional lakukan.

Akhirnya, kecenderungan membosankan jika proses belajar mengajar yang monoton dilakukan didalam kelas. Jika ada kesempatan untuk pergi ke lapangan dan langsung berinteraksi ke praktek apakah responden bersedia. Sebanyak 38 orang mahasiswa setuju jika dosen mengajak ke laboratorium lapangan dan sisanya sebanyak 22 orang mahasiswa dengan responden sangat setuju dilakukannya kunjungan seperti di Bursa Efek Indonesia di Surabaya, Kantor Pelayanan Pajak di Tulungagung, KJA yang ada di karesidenan Kediri dan lain sebgaianya. Anggapan mengenai pengetahuan mata kuliah konvensional membantu berorganisasi atau kegiatan lainnya di kampus maupun di masyarakat dikemukakan oleh 58 orang responden dan 2 orang tidak setuju dengan pernyataan tersebut. Diagram dapat dilihat dibawah ini. Rencana responden kedepanya setelah menyelesaikan perkuliahaan di jurusan hes akan menempuh jenjang yang lebih tinggi ke ekonomi 
konvensional ada 20 orang mahasiswa, dan sebanyak 40 orang mahasiswa tidak akan mengambil jurusan jurusan ekonomi konvensional. Ada beberapa alasan tidak setuju yang didapat dari hasil wawancara yaitu, karena ada responden yang tidak ada rencana melanjutukan kuliah lagi dan ada responden yang berencana menempuh jenjang kuliah yang lebih tinggi namun bukan di jurusan ekonomi konvensional

\section{B. Gambaran Umum Responden}

Responden yang terdiri dari mahasiswa HES yang berpartisipasi dalam penelitian ini semuanya telah mengambil mata kuliah pengantar akuntansi dan perpajakan. Mata kuliah pengantar akuntansi merupakan matakuliah prasyarat untuk mengambil mata kuliah perpajakan. Berikut perolehan nilai dari perkuliahan pengantar akuntansi yang sudah mereka ambil sebelumnya:

Tabel 1. Nilai Mata Kuliah Pengantar Akuntansi

\begin{tabular}{|l|r|r|}
\hline \multicolumn{1}{|c|}{ Nilai MK } & Jumlah Mhs & $\begin{array}{c}\text { Prosentase } \\
\text { (\%) }\end{array}$ \\
\hline A+ & 17 & 27,87 \\
\hline A & 24 & 39,34 \\
\hline A- & 16 & 26,23 \\
\hline B+ & 0 & - \\
\hline B & 0 & - \\
\hline B- & 3 & 4,92 \\
\hline C+ & 1 & - \\
\hline C & 1,64 \\
\hline C- & & \\
\hline D & & \\
\hline Tidak Bersedia & & 100 \\
\hline memberitahu & & \\
\hline \multicolumn{2}{|c|}{ Jumlah } & 61 \\
\hline
\end{tabular}

Dari table di atas mahasiswa yang menjadi responden mempunyai nilai yang bervariasi, tetapi dari nilai tersebut rata-rata mendapatkan nilai yang baik. Terlihat nilai tertinggi berkisar $27,87 \%$ atau sebanyak 17 orang mendapatkan nilai A. Sementara angka terendah sebanyak $1,64 \%$ atau 1 orang mendapatkan nilai C. Dari data responden rata-rata mendapatkan hasil yang cukup memuaskan dari mata kuliah pengantar akuntansi yang mereka ambil sebelumnya. 
Tabel 2. Nilai Mata Kuliah Perpajakan

\begin{tabular}{|c|c|c|}
\hline Nilai MK & Jumlah Mhs & $\begin{array}{c}\text { Prosentase } \\
(\%) \\
\end{array}$ \\
\hline$A+$ & 12 & 20 \\
\hline $\mathrm{A}$ & 17 & 28,33 \\
\hline A- & 14 & 23,33 \\
\hline $\mathrm{B}+$ & 9 & 15,00 \\
\hline B & 7 & 11,67 \\
\hline B- & 1 & 1,67 \\
\hline $\mathrm{C}+$ & 0 & 0,00 \\
\hline C & 0 & 0,00 \\
\hline C- & 0 & 0,00 \\
\hline $\mathrm{D}$ & 0 & 0,00 \\
\hline \multicolumn{3}{|l|}{$\begin{array}{l}\text { Tidak Bersedia } \\
\text { memberitahu }\end{array}$} \\
\hline Jumlah & 60 & 100 \\
\hline
\end{tabular}

Begitupula dengan matakuliah pengantar akuntansi, matakuliah perpajakan mahasiswa yang menjadi responden mempunyai nilai yang bervariasi dan nilai tersebut rata-rata mendapatkan nilai yang baik. Terlihat nilai tertinggi berkisar 20\% atau sebanyak 12 orang mendapatkan nilai A+. Sementara angka terendah sebanyak $1,64 \%$ atau 1 orang mendapatkan nilai B-. Dari data responden rata-rata mendapatkan hasil yang cukup memuaskan dari mata kuliah perpajakan.

Jumlah responden tidak jauh berbeda yang mengambil matakuliah pengantar akuntansi dan perpajakan, dengan asumsi semuanya baru mengambil dan tidak ada mahasiswa yang mengulang pada mata kuliah baik pengantar akuntansi dan perpajakan.

Tabel 3. Manfaat mempelajari pengantar akuntansi dan perpajakan

\begin{tabular}{|l|r|r|}
\hline \multicolumn{1}{|c|}{ Manfaat setelah mengambil } & Jumlah Responden (orang) & Prosentase \\
\hline Bisa diterapkan dalam berorganisasi & 33 & $55 \%$ \\
\hline Bermanfaat namun tidak ada hubungannya & 24 & $40 \%$ \\
\hline Tidak bermanfaat & 2 & $3 \%$ \\
\hline Tidak bisa bermanfaat sama sekali & 1 & $2 \%$ \\
\hline JUMLAH & 60 & $100 \%$ \\
\hline
\end{tabular}

Mahasiswa berpendapat sebanyak 55\% atau 33 orang bahwa, setelah mendapatkan matakuliah pengantar akuntansi dan perpajakan bisa menambahan 
wawasan keilmuan dan mampu mengaplikasikan di organisasi baik di dalam kampus maupun di luar kampus, misalnya pada saat KKN maupun pada saat PPL. Pengaplikasian matakuliah dalam konteks sebatas sebagai penerapan-penerapan yang sederhana,misalnya sebagai bendahara PPL, informan jika ada perangkat desa yang menanyakan batas akhir penyampaian pajak PPh 21 dan sebagainya.

Reseponden sebanyak $40 \%$ atau 24 orang menyatakan bahwa, antara matakuliah akuntansi dan perpajakan bisa menambahan wawasan keilmuan,namun penerapannya belum signifikan dengan keadaan saat ini. Responden beranggapan bahwa peneraan matakuliah pengantar akuntansi dan perpajakan hanya bisa diterapkan pada perusahaan. Hal tersebut dapat dimaklumi, karena responden merupakan notabenenya sebagian besar latar belakangnya dari pendidikan yang belum mengenal pendidikan ekonomi.

Dari angka sebagian besar responden menyatakan bahwa ilmu pengantar akuntansi dan perpajakan sangat bermanfaat untuk diterapkan dalam lingkungan organisasi baik di organisasi dalam kampus maupun di luar kampus. Dengan demikian, dapat disimpulkan bahwa dengan mempelajari ekonomi konvensional (pengantar akuntansi dan perpajakan) sebagai ilmu pendukung, mahasiswa merasakan manfaatnya yang sangat besar secara langsung maupun masa yang akan datang sebagai penegak hukum.

Tabel 4. Faktor yang mempengaruhi keberhasilan menempuh matakuliah

\begin{tabular}{|l|r|r|}
\hline Faktor & Responden (orang) & Prosentase \\
\hline Motivasi mahasiswa sendiri & 6 & $10 \%$ \\
\hline Metode ajar & 15 & $25 \%$ \\
\hline Kelengkapan fasilitas & 6 & $10 \%$ \\
\hline Wawasan dan cara transfer ilmu dosen & 33 & $55 \%$ \\
\hline Jumlah & 60 & $100 \%$ \\
\hline
\end{tabular}

Dari data tersebut, responden memberikan pendapat tentang pengaruh dan relevansi belajar ekonomi konvensional (pengantar akuntansi dan perpajakan) bahwa yang mempengaruhi tingkat keberhasilan dalam belajarnya yang tidak jauh berbeda yaitu: adanya wawasan dan cara transfer ilmu dosen saat mengajar (55\%) dan motode ajar (25\%). Sedangkan motivasi mahasiswa (12\%) dan kelengkapan 
fasilitas (12\%) memiliki prosentase yang sama. Menurut responden berpengaruh. Jika LCD di ruangan mati akan mempengaruhi dalam proses belajar mengajar. Sedangkan motivasi tersebut, dikarenakan responden sebagian besar lulusan non ekonomi.

Tabel 5. Pengaruh mata kuliah ekonomi konvensional terhadap mata kuliah matakuliah lainnya

\begin{tabular}{|c|c|c|}
\hline \begin{tabular}{|lrl} 
Pengaruh & matakuliah & ekonomi \\
konvensional terhadap matakuliah lainnya
\end{tabular} & $\begin{array}{l}\text { Jumlah } \\
\text { Responden } \\
\text { (orang) }\end{array}$ & $\%$ \\
\hline Menjadi lebih mudah & 11 & $18 \%$ \\
\hline $\begin{array}{l}\text { Lebih mudah tapi tidak } \\
\text { Signifikan }\end{array}$ & 31 & $52 \%$ \\
\hline $\begin{array}{|ll|}\text { Tidak } & \text { ada manfaat } \\
\text { Mempelajari } & \\
\text { Sebelumnya } & \\
\end{array}$ & 10 & $17 \%$ \\
\hline $\begin{array}{l}\text { Tetap } \\
\text { harus belajar keras }\end{array}$ & 8 & $13 \%$ \\
\hline TOTAL & 60 & $100 \%$ \\
\hline
\end{tabular}

Selain mengetahui pengaruh perubahan pemahaman responden setelah mempelajari matakuliah ekonomi konvensional, mereka ditanyakan pengaruh terhadap mata kuliah berikutnya. Dari table 5 dapat dilihat, hampir sebagian besar merasakan pengaruhnya, sebesar $52 \%$ responden menyatakan bahwa lebih mudah namun tidak signifikan. Pemahaman responden menyatakan bahwa antara matakuliah ekonomi konvensional dengan matakuliah yang berhubungan dengan hukum islam belum berkorelasi secara signifikan. Responden $8 \%$ menyatakan bahwa matakuliah ekonomi konvensional tidak mempunyai korelasi yang signifikan.

Tabel 6. Perubahan Motivasi dan Cara Pandang pada Mata Kuliah SI Saat Ini

\begin{tabular}{|l|l|l|}
\hline $\begin{array}{l}\text { Perubahan Motivasi dan } \\
\text { Cara Pandang pada Mata } \\
\text { Kuliah ekonomi konvesional Saat } \\
\text { Ini }\end{array}$ & $\begin{array}{l}\text { Jumlah } \\
\text { responden } \\
\text { (orang) }\end{array}$ & $\%$ \\
\hline $\begin{array}{l}\text { Lebih Termotivasi dan } \\
\text { Menikmati termotivasi karena }\end{array}$ & 18 & $30 \%$ \\
\hline $\begin{array}{l}\text { Lebih k termotivasi karena } \\
\text { tidak mau mengulang }\end{array}$ & 28 & $47 \%$ \\
\hline $\begin{array}{l}\text { Tidak kuliah } \\
\text { lebih tidak menarik dari mata } \\
\text { no ekonomi }\end{array}$ & 4 & $7 \%$ \\
\hline
\end{tabular}




\begin{tabular}{|l|l|l|}
\hline $\begin{array}{l}\text { Sama saja dengan matakuliah non } \\
\text { ekonomi }\end{array}$ & 10 & $16 \%$ \\
\hline TOTAL & $\mathbf{6 0}$ & $\begin{array}{l}100 \\
\%\end{array}$ \\
\hline
\end{tabular}

Pada table 6, responden diminta peneliti untuk membandingkan antara motivasi dan cara pandang mereka saat mempelajari ekonomi konvensional dengan kondisi wawasan dan persepsi mereka saat mengambil mata kuliah lanjutan yang sedang mereka pelajari. Dari seluruh responden 77\% menyatakan termotivasi saat mengambil mata kuliah ekonomi konvensional, dengan terbagi menjadi 2 pendapat yaitu 47\% termotivasi karena tidak ingin mengulang dan yang 30\% sangat menikmati matakuliah ekonomi konvensional. Menurut pendapat responden, matakuliah ekonomi konvensional sangat dibutuhkan bagi calon penegak hukum dikemudian hari. Responden sebanyak 23\% menyatakan tidak termotivasi terhadap matakuliah konvensional, karena dirasa tidak menarik dan membosankan saat mengambil matakuliah ekonomi konvensional.

\section{Uji Validitas dan Reliabilitas}

Validitas merupakan ukuran yang menunjukkan bahwa variable yang diukur memang benar-benar variable yang hendak diteliti oleh peneliti. Ghozali, menyatakan bahwa uji validitas digunakan untuk mengukur sah atau valid tidaknya suatu kuesioner. (qmc.binus.ac.id).

Sugiharto dan Sitinjak, menyatakan bahwa reliabilitas menunjuk pada suatu pengertian bahwa instrumen yang digunakan dalam penelitian untuk memperoleh informasi yang digunakan dapat dipercaya sebagai alat pengumpulan data dan mampu mengungkap informasi yang sebenarnya di lapangan. Bila suatu alat pengukur dipakai dua kali untuk mengukur gejala yang sama dan hasil pengukuran yang diperoleh relatif konsisten, maka alat pengukur tersebut reliable. Dengan kata lain, realibitas menunjukkan konsistensi suatu alat pengukur di dalam pengukur gejala yang sama.

Reliability Statistics- pertanyaan

kelompok B 


\begin{tabular}{|l|l|l|}
$\begin{array}{l}\text { Cronbach's } \\
\text { Alpha }\end{array}$ & $\begin{array}{l}\text { Standardized } \\
\text { Items }\end{array}$ & $\begin{array}{l}\mathrm{N} \text { of } \\
\text { Items }\end{array}$ \\
\hline .630 & .632 & 5 \\
\hline
\end{tabular}

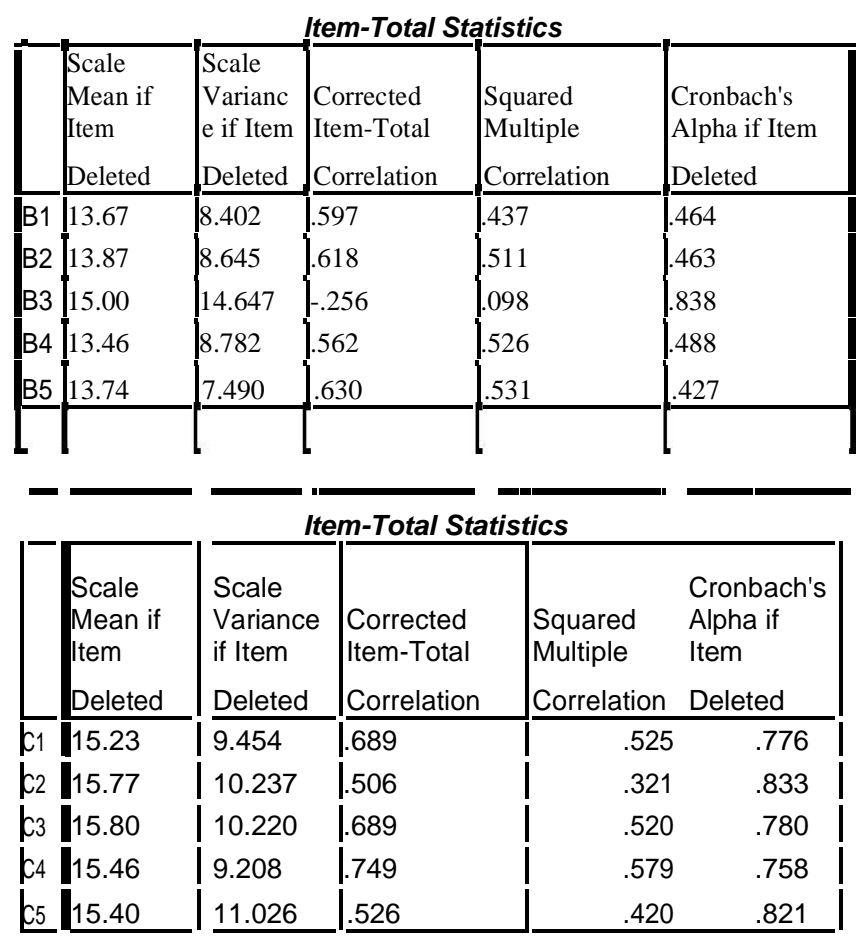

\begin{tabular}{|c|c|c|c|c|c|c|}
\hline & $\begin{array}{l}\text { Scale } \\
\text { Mean if } \\
\text { Item } \\
\text { Deleted }\end{array}$ & $\begin{array}{l}\text { Scale } \\
\text { Varianc } \\
\text { e if Item } \\
\text { Deleted } \\
\end{array}$ & $\begin{array}{l}\text { Corrected } \\
\text { Item-Total } \\
\text { Correlation }\end{array}$ & $\begin{array}{l}\text { Squared } \\
\text { Multiple } \\
\text { Correlation }\end{array}$ & \multicolumn{2}{|c|}{$\begin{array}{c}\text { Cronbach's } \\
\text { Alpha if Item } \\
\text { Deleted }\end{array}$} \\
\hline D1 & 15.04 & 13.013 & .561 & & .363 & $\begin{array}{l}.58 \\
6\end{array}$ \\
\hline D2 & 15.38 & 12.444 & .562 & & .382 &.$^{58}$ \\
\hline D3 & 15.13 & 14.586 & .321 & & 139 & $\begin{array}{l}68 \\
6\end{array}$ \\
\hline D4 & 15.06 & 13.702 & .420 & & .218 & $\begin{array}{l}.64 \\
5\end{array}$ \\
\hline D5 & 15.28 & 14.055 & .359 & & .138 & $\begin{array}{l}67 \\
2\end{array}$ \\
\hline
\end{tabular}

Reliability Statistics- pertanyaan kelompok C

\begin{tabular}{|l|l|l|}
\hline Cronbach's & $\begin{array}{l}\text { Cronbach's Alpha } \\
\text { Based on } \\
\text { Standardized } \\
\text { Alpha }\end{array}$ & N of \\
\hline Items & Items \\
\hline 829 & Item \\
\hline
\end{tabular}

Reliability Statistics - pertanyaan

\section{kelompok D}

\begin{tabular}{|l|l|} 
Cronbach's & $\begin{array}{l}\text { Cronbach's Alpha } \\
\text { Based on } \\
\text { Standardized }\end{array}$
\end{tabular} \mid \begin{tabular}{|l} 
N of \\
\hline
\end{tabular}

Persepsi Mahasiswa Hukum Ekonomi Syariah (Hes) Terhadap Mata Kuliah Ekonomi Konvensional

https:// doi.org/10.35457/akuntabilitas.v12i1.720

(C) 2019 Akuntabilitas: Jurnal Ilmu-Ilmu Ekonomi. Semua hak cipta dilindungi undang-undang 


\begin{tabular}{|l|l|l|}
\hline Alpha & Items & Items \\
\hline .686 & .689 & 5 \\
\hline
\end{tabular}

Untuk semua pertanyaan terlihat bahwa angka cronbach's alpha lebih dari 0.5 (atau mendekati angka 1) sehingga bisa disimpulkan bahwa semua pertanyaan pada kelompok ini lulus uji reliabilitas. Bisa disimpulkan dari table bahwa pertanyaan pada masing-masing kelompok reliable sebesar 63\%, 82.9\% dan $68.6 \%$. Sehingga bisa diambil kesimpulan bahwa semua item pertanyaan didalam kuesioner selain valid juga reliable.

\section{Analisis Deskriptif}

Seperti halnya analisis statistic yang dilakukan oleh surya dan setiyaningrum (2009) yang memiliki karakteristik pengolahan data yang mirip dengan penelitian persepsi yang penulis lakukan, analisis akan dilakukan dengan menggunakan table distribusi frekuensi. Pada table tersebut akan dihitung nilai rata-rata (Mean). Distribusi frekuensi iniberfungsi untuk mengkalkulasi besarnya frekuensi data dari masing-masing kelompok data. Rumus yang akan digunakan untuk menghitung Mean sesuai dengan yang dikemukakan oleh Supranto (1994) dalam surya dan setiyaningrum, yaitu:

$\mathrm{Me}=\frac{\mathrm{fi} \mathrm{xi}}{\mathrm{n}}$

Dimana:

fi : merupakan jumlah frekuensi

xi : merupakan nilai/ bobot variable n merupakan jumlah responden.

Pengelompokan setiap indikator dihitung berdasarkan pemberian bobot nilai yang diperoleh dari hasil kuesioner dengan cara perhitungan rentang skala yang diperoleh sebagai berikut:

Nilai tertinggi $=$ total responden $\times$ bobot tertinggi $=60 \times 5=300$ Nilai terendah $=$ total responden $\times$ bobot terendah $=60 \times 1=70$ Rentang skala $=$ nilai tertinggi - nilai terendah $=(300-60) / 5=48$

1. Persepsi tentang relevansi pengajaran sistem informasi dengan bidang ilmu akuntansi 


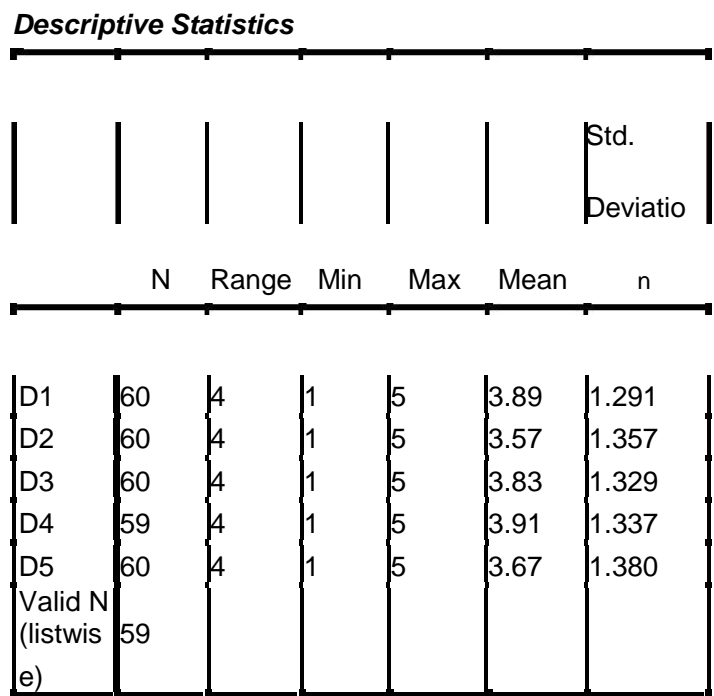

Interpretasi hasil perhitungan rata-rata:

3,28 - 5.00 = Sangat Setuju (SS)

$2,71-3,27=$ Setuju $(S)$

2,14 - 2,70 = Cukup Setuju (CS)

$1,57-2,13=$ Kurang Setuju (KS)

$1,00-1,56=$ Tidak Setuju (TS)

Kelompok pertanyaan B berkaitan dengan seberapa besar relevansi pengajaran ekonomi konvensional, hampir semua pertanyaan memiliki Mean pada interval teratas yaitu diatas 3,28. Ini menjelaskan bahwa hampir semua responden sangat setuju dan memiliki persepsi positif bahwa pengajaran ekonomi konvesional yang sangat relevan dengan bidang ilmu hukum. Responden sangat memahami pentingnya mata kuliah ini dalam mendukung wawasan hukum islam yang mereka miliki. Selain itu responden meyakini bahwa ilmu ekonomi konvensional dan hukum baik hukum konvensional maupun hukum islam sangat mempengaruhi keberhasilan penegak hukum di masa yang akan datang. Bahkan responden juga memiliki persepsi bahwa tanpa ilmu dan pemahaman tentang ekonomi konvensional yang baik, maka penegak hukum tidak akan bisa melaksanakan tugas dan pekerjaannya dengan maksimal.

2. Persepsi tentang manfaat dan urgensi pengajaran ekonomi konvensional 
Interpretasi hasil perhitungan rata-rata:

$$
\begin{aligned}
& 3,28-5.00=\text { Sangat Penting }(\mathrm{SP}) \\
& 2,71-3,27=\text { Penting }(\mathrm{P}) \\
& 2,14-2,70=\text { Cukup Penting }(\mathrm{CP}) \\
& 1,57-2,13=\text { Kurang Penting }(\mathrm{KP}) \\
& 1,00-1,56=\text { Tidak Penting }(\mathrm{TS})
\end{aligned}
$$

Sesuai dengan penghitungan Mean yang berasal dari table di atas terlihat bahwa semua butir pertanyaan memiiliki Mean di interval teratas. Ini berarti bahwa semua butir pertanyaan membuktikan persepsi responden tentang bermanfaat dan urgennya pengajaran ekonomi konvensional bagi mahasiswa di jurusan HES. Responden meyakini, semua pekerjaan dan tugas penegak hukum tidak bisa lepas dari informasi ekonomi konvensional. Responden juga menyatakan penting untuk mengambil mata kuliah pendukung lainnya selain mata kuliah pengantar akuntansi dan perpajakan. Yang mana mata kuliah ekonomi konvensional bisa menjadikan pegangan untuk penegak hukum dalam menyelesaikan masalah ekonomi, mempengaruhi perkembangan karir mereka nantinya kalo sudah menjadi penegak hukum.

3. Persepsi tentang factor-faktor yang menghambat pengajaran sistem informasi di Jurusan Akuntansi

Interpretasi hasil perhitungan rata-rata: 3,28 $-5.00=$ Sangat Menghambat $(\mathrm{SM})$

2,71 - 3,27 = Menghambat $(\mathrm{M})$

2,14 $-2,70=$ Cukup Menghambat $(\mathrm{CM})$

1,57 - 2,13 = Kurang Menghambat (KM)

$1,00-1,56=$ Tidak Menghambat $(\mathrm{TM})$

Descriptive Statistics

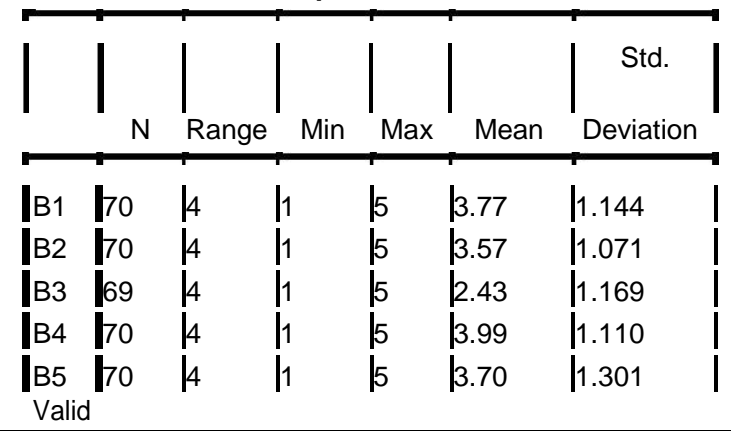




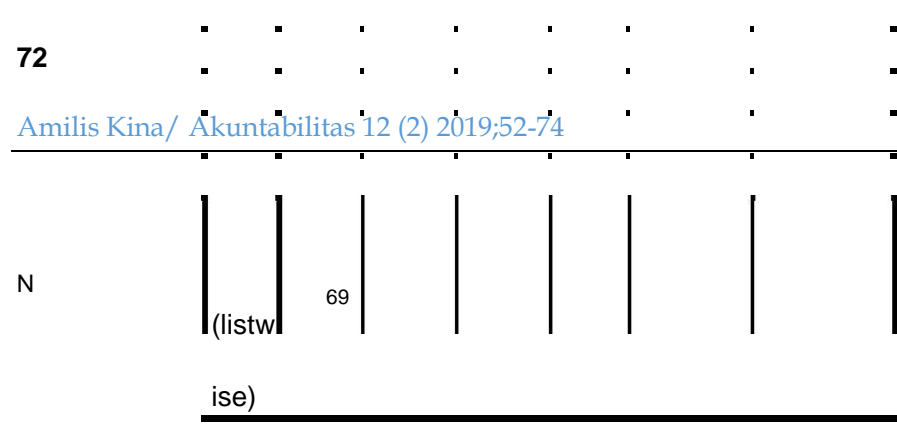

Faktor-faktor yang diuraikan di setiap pertanyaan pada kelompok ini memiliki angka rata-rata (Mean) yang tinggi (pada interval teratas). Dapat disimpulkan bahwasanya semua pertanyaan yang dikemukakan itu dianggap sangat menghambat pengajaran ekonomi konvensional di jurusan HES. Adapun faktor yang dianggap penghambat antara lain:

1. Minat dan motivasi yang rendah belajar ekonomi konvensional;

2. Persepsi negative mahasiswa tentang relevansi ekonomi konvensional dengan bidang ilmu hukum;

3. Cara penyampaian dan transfer ilmu dosen (masih konvensional dan teacher center learning).

4. Kurangnya fasilitas pendukung;

5. Wawasan dosen yang mereka anggap kurang;

6. Dan lain-lain.

\section{PENUTUP}

Berdasarka penelitian yang dilakukan terhadap mahasiswa jurusan HES mengenai persepsi mereka terhadap mata kuliah ekonomi konvensional dapat disimpulkan beberapa hal sebagai berikut:

Responden memiliki persepsi yang positif tentang pentingnya mempelajari ekonomi konvensional dan relevansinya dengan peningkatan wawasan bidang keilmuan ekonomi konvensional. Responden percaya bahwa ekonomi konvensional dapat membantu masalah-masalah hukum tertentu. Dan eonomi konvensional dapat membuat peluang kemudahan dan kelancaran dalam menjalani karir nantinya sebagai penegak hukum.

Responden terbukti memiliki persepsi positif terhadap pembelajaran ekonomi konvensional. Pembelajaran tersebut memberi manfaat dalam mendapatkan penilaian yang baik. Ditemukan bahwa terdapat banyak factor yang mempengaruhi mahasiswa HES dalam mempelajari ekonomi konvensional. Dapat dilihat 
bahwasanya factor penting berada pada factor SDM yaitu mahasiswa itu sendiri dan dosen sebagai penyampai materi. Motivasi, cara pandang mahasiswa serta wawasan dosen penyampai materi diyakini oleh para responden sebagai factor utama yang berpengaruh terhadap keberhasilan mereka dalam mempelajari mata kuliah ekonomi konvensional ini.Faktor-faktor yang dianggap menghambat proses pembelajaran sistem informasi di jurusan HES adalah sebagai berikut:

a) Minat dan motivasi yang rendah untuk belajar ekonomi konvensional;

b) Persepsi negative mahasiswa tentang relevansi sistem informasi dengan bidang ilmu ekonomi konvensional.

c) Cara penyampaiankan dan transfer ilmu dosen;

d) Kurangnya fasilitas pendukung metode interaktif yang menarik dan melibatkan tekhnologi informasi.

e) Wawasan dosen yang mereka anggap kurang

Besar harapan dari responden yang terlihat dari banyaknya yang memberikan saran agar perkuliahan ekonomi konvensional menjadi mata kuliah berkelanjutan. Dimana ada matakuliah yang bisa mempersatukan antara ekonomi konvensional dan hukum.

Berdasarkan kesimpulan diatas, maka dosen hendaklah lebih memperhatikan tugas dan tanggungjawab dalam membantu mahasiswa HES sehingga tujuan dapat dicapai dengan baik. dosen memberikan bantuan dan bimbingan sebagaimana mestinya khususnya pada mata kuliah ekonomi konvensional. sebagai unit pelaksana dari universitas seharusnya mengkaji kembali diberikannya mata kuliah ekonomi konvensional. Para dosen harus mengadakan pembinaan dengan mahasiswa HES sehingga mahasiswa mengetahui tugas dan tanggungjawab mereka selama belajar ekonomi konvensional. Seiring dengan pemenuhan kebutuhan matakuliah ekonomi konvensional, mahasiswa HES juga harus aktif mendiskusikan semua kegiatan belajar mereka dengan dosen dalam usaha meningkatkan kemampuan dalam menguasai matakuliah ekonomi konvensional

\section{DAFTAR PUSTAKA}


Adriansyah. 2011. Persepsi Mahasiswa Akuntansi dan Praktisi Akuntansi Syariah Terhadap Praktisi Akuntansi Syariah di Indonesia. Makasar.

A.M. saifuddin ; studi system ekonomi islam, (Jakarta : Media dakwah, 1984).

Burhan Bungin. 2011. Metodologi penelitian kuantitatif, Jakarta: kencana prenada media group

Chaedar Alwasilah. Pokoknya Kualitatif(Dasar-Dasar Merancang dan Melakukan Penelitian Kualitatif).Jakarta:PT. Dunia Pustaka Jaya.2011

Diana,Anastasya dan Lilis Setiawati, Perpajakan Indonesia, (Jogjakarta: C.V ANDI OFFSET,2009).

Jusup, Al. Haryono.2010. Dasar-Dasar Akuntansi 2. Edisi 7. Yogyakarta: Bagian Penerbitan STIE YKPN.

Mardiasmo, 2010, Perpajakan, Edisi Revisi, Cetakan Kesepuluh, Penerbit: Andi, Jakarta.

Sugiyono.(2010). MetodePenelitian Kuantitatif Kualitatif \& RND. Bandung : Alfabeta.

Sugiyono. 2005. Metode Penelitian Administrasi. Bandung : Alfabeta.

Suharsimi Arikunto. (2002). Prosedur Penelitian Suatu Pendekatan Praktek Edisi Revisi V. Jakarta : Rineka Cipta. Hlm.109Slameto. (2013). Belajar dan Faktor-Faktor yang Mempengaruhi. Jakarta: Rineka Cipta.

Sarlito W. Sarwono. Pengantar Psikologi Umum. Jakarta: Rajawali Pers.2012.

Syamsuddin, dkk. 2011. Metode Penelitian Pendidikan Bahasa. Bandung: PT. Remaja Rosdakarya. 
Persepsi Mahasiswa Hukum Ekonomi Syariah (Hes) Terhadap Mata Kuliah Ekonomi Konvensional https:// doi.org/10.35457/akuntabilitas.v12i1.720

(C) 2019 Akuntabilitas: Jurnal Ilmu-Ilmu Ekonomi. Semua hak cipta dilindungi undang-undang 